\title{
INTELLECTUAL MIGRATION AS AN ISSUE OF CONTEMPORARY EDUCATION IN UKRAINE
}

\author{
Oksana Abreu Bastos \\ Center for Social Studies (CES) at the University of Coimbra, Coimbra, Portugal \\ Vladyslav Koshulko \\ Karol Adamiecki University of Economics in Katowice, Katowice, Poland
}

\section{() MESTE NGO}

JEL code: F2, F22, H7, 12, 129, O15, R23

\begin{abstract}
This article discusses the causes and consequences of intellectual migration, brain drain, or the migration of Ukrainian scientists and educators from Ukraine. Causes for brain drain are: lack of reforms in education and science; low public spending on science and education; no conditions for work; the artificial obstacles for obtaining foreign grants and scholarships; no material and housing conditions; no moral or psychological freedom; no decent wages. Consequences of brain drain are: lack of reforms in the state; the significant lag in education, science, and in socio-economic and cultural areas; isolation from worldwide innovation and progress; political and socio-economic crisis; loss the status of the scientific country. Also this paper examines the dynamic of the reduction in the number of scientists from 1990-2012. The conclusions of the study are assumptions about the negative consequences of the current situation in the Ukrainian education and science system for Ukraine's future. We are sure that only real and consistent reforms of science and education can protect the Ukrainian system of education and science from irreversible processes. The country needs real reforms that could accumulate the human capital of Ukrainian scientists and educators through the creation of reasonable living and working conditions for them inside the country, not abroad. Otherwise, Ukraine could lose its status as a scientific state.
\end{abstract}

Keywords: Ukraine, intellectual migration, brain drain, education, science, human capital, worldwide, scientists, educators, reforms of science and education, causes, consequences

\section{INTRODUCTION}

One of the most complex social phenomena in the modern Ukrainian migration is the brain drain

The address of the corresponding author:

\section{Oksana Abreu Bastos}

拝" abreubastos.oksana@gmail.com abroad. The most important and serious problem of modern Ukraine is the very difficult situation in the Ukrainian system of education and science, and its impact on Ukrainian society in general, and, as a consequence, the migration of the Ukrainian scientists and educators abroad. The brain drain results from the opportunities abroad 
for Ukrainian scientists and educators to use their human capital and their knowledge very effectively, and at the same time to improve their financial situation.

According to experts, a significant brain drain results in the loss of national wealth of Ukraine resulting in the spiritual impoverishment of the nation.

\section{THE BRAIN DRAIN OF UKRAINIAN SCIENTISTS AND EDUCATORS}

Migration is a natural process, which is associated with the development of the internationalization of scientific and technological activities.

Thus, highly skilled professionals, scientists and educators, leave Ukraine to arrive in countries with better conditions for their scientific activity.

But at the same time brain drain is a serious signal to countries, including Ukraine, and because Ukraine is a third world country the brain drain in Ukraine continues as well. In general brain drain is "a serious challenge for African countries, such as Ethiopia, Kenya, Nigeria, for countries of Latin America, and for other countries too" (Skrypnyk, 2013).

Every year, thousands of professionals, scientists and educators, those that have themselves been trained by professionals, are going to the United States, Canada, Germany, Israel, Spain, Italy, and Russia, thereby investing in these countries.

The countries receiving these scientists also receive huge revenues. The last U.S. census showed that $22.4 \%$ of U.S. citizens with advanced degrees are of foreign origin. This category includes $16.5 \%$ scientists and engineers with a bachelor's degree, $20 \%$ - with a master's degree, and $37.6 \%$ - with the degree of Doctor of Science (Danilishin, 2006).

By the methods of calculation of a UN research organization, the donor country loses the equivalent of about 300,000 USD per year. The countries receiving this human capital, in turn, get the opportunity to save significant funds for their creation and accumulation (Borodina, 2003).

The most attractive for them are Russia, the USA, and Germany. These countries account for
$65 \%$ of Ukraine's total number of intellectual emigrants abroad. Nearly one in seven of them work in the fields of physical and mathematical sciences, one in five works in technical or biological areas (Danilishin, 2006).

Although data from several sources is inconsistent regarding the number of scientists who leave the country, every source agrees on one thing: brain drain is a serious signal to the state, therefore today we need to think about the future of Ukraine.

\section{ANALYSES OF UKRAINIAN EXPERTS' RESEARCH ON BRAIN DRAIN}

According to studies of $\mathrm{O}$. Meh, the largest mass departure of scientists with $\mathrm{PhD}$ degrees was in the 1990s. From 1991-1999, the country lost 268 PhD's, who took up permanent residence abroad (Meh, 2012);

According to studies of ex-Ombudsman N. Karpachova of Ukraine, from 1993-2003, 574 doctors and 907 candidates of the sciences emigrated from Ukraine (Karpachova, 2003; 2005);

According to studies of B. Danilishin and V. Kutsenko, in 2004 alone, more than 600 PhD's emigrated from Ukraine (Danilishin, 2006);

According to studies of $\mathrm{O}$. Golovinov, in recent years Ukraine has lost nearly 5-5.5 thousand scientists (Golovinov, 2004);

According to studies of A. Chukhno, more than 6 thousand scientists left the country in search of work and the opportunity to realize their knowledge (Chukhno, 2003);

According to studies of $\mathrm{V}$. Polokhalo, between 1991 and 2011, the number of doctors and candidates of the sciences involved in scientific and technical activities decreased by 8,848 (28\%) (Polokhalo, 2011).

In general, the costs of training a highly skilled scientific and technical profile for the donor country are nearly 800,000 USD.

This amounts to a huge loss for Ukraine. And if to the category of scientists and educators we add highly-qualified engineers, technicians, physicians, and cultural workers, the loss of Ukraine will be much more (Golovinov, 2004). 
4

$\begin{array}{lccc}\text { THE MAIN } & \text { REASONS } & \text { FOR THE } \\ \text { DEPARTURE } & \text { OF } & \text { UKRAINIAN } \\ \text { SCIENTISTS AND EDUCATORS ABROAD }\end{array}$

What are the main reasons for the departure of Ukrainian scientists and educators abroad?

It is the devaluation of the educational potential, the destruction of the policy of regional development, the weak state regulation of labor relations, etc. (Golovinov, 2004).

According to studies of A. Sych, other significant reasons for the Ukrainian brain drain are (Sych, 2013):
a) The intense commercialization of Ukrainian education;
b) A significant intensification of jobs in addition to the extremely low wages of scientists and educators;
c) Lack of material resources for development;
d) The absence of innovation infrastructures in the scientific institutions of Ukraine;
e) Inefficient scientific activities of university teachers;
f) An outdated structure of training, playback and the transmission of ineffective knowledge to students.

We fully subscribe to the statement of $S$. Kvit on the state of contemporary Ukrainian Education and Science, which is an exhaustive answer to the question about the causes of the brain drain of Ukraine:

"The situation in Ukraine probably reflects the worst of all the post-Soviet systems. ... Ukraine cannot demonstrate any benefits that have come its way in connection with post-Soviet changes to its higher education system since 1991. ...In all the former Soviet republics apart from the Baltics, the legacy of the Soviet days remains. They have similar rules still in force, have structurally similar higher education institutions and a similar research infrastructure, and post-Soviet patriotism and corruption are common» (Kvit, 2013).

So, Ukraine has created all of the conditions for brain drain. This phenomenon is still in progress in the country, because the modern Ukrainian system of education and science does not allow the Ukrainian progressive scientists, who speak foreign languages, to evolve and get a worthwhile reward as the fruits of their labor in their country of origin.

This system does not allow the Ukrainian scientists to maintain their human capital at the level of world standards, because it:

a) Does not create conditions for their work and their creativity;

b) Often makes it impossible for them to take part in the international competitions of foreign grants and scholarships, thus preventing the development of their human capital;

c) Does not care about their material and housing difficulties;

d) Inhibits them morally and psychologically;

e) Does not pay them properly for a scientist's work, because the state is trying to maximize savings through their wages.

Therefore, these and other factors are pushing scientists to travel abroad.

\section{THE COUNTRIES THAT BENEFIT FROM UKRAINE'S BRAIN DRAIN}

We assume that the vast majority of Ukrainian scientists of the former Soviet Union, who in the 1990's and 2000's went abroad, did not speak the European languages, so, most of them left for permanent residence in countries of the former socialist camp, or in the countries of the former Soviet Union, where they found better living conditions and a comfortable environment for their research. Fewer scientists left Ukraine and went to the USA and EU countries: Germany, Poland, France, Italy, Portugal, etc.

Today, the vast majority of the young Ukrainian scientists who are leaving Ukraine for work and permanent residence abroad are fluent in English or other European languages, depending on the country to which they are heading (Abreu Bastos, 2013).

As the situation in the field of higher education and science has not improved from the first wave of intellectual emigrants 20 years ago, nor has the conditions in Ukraine in general, brain drain continues much more strongly today. 


\section{THE CURRENT SITUATION IN} UKRAINIAN UNIVERSITIES

Education today has moved away from the traditional allocation of resources, and has become a big business. (Poplavskaya, 2002);

Corruption and bribery have penetrated into all areas of higher education. As a consequence, in 2012, according to research by the International Organization "Transparency International," Ukraine was the most corrupt country in Europe (Kalts, 2012).

Universities have forced scientists and educators to go on unpaid vacations "at their will" (Anon, 2012) in times when their salaries are among the lowest in their fields in Europe, only 350-400 USD per month (Koshulko, 2012A).

The wage level of the Ukrainian scientists at 350400 USD per month helps to explain the brain drain. This is the great benefit for the recipient country, getting the ready trained professionals from a country that doesn't want to take care of its scientists and educators. Because, how can we otherwise explain the tenfold difference in pay of an Associate Professor with a Ph.D. between Ukraine and countries of the EU?

We can explain this situation only by the lack of desire of Ukraine to take care of its citizens, the Ukrainian scientists and educators, and the other people as well (Abreu Bastos, 2013).

\section{REDUCING UNIVERSITY TEACHERS IN A NEW WAVE OF THE BRAIN DRAIN OF UKRAINE}

In one of the initiatives under the Action Plan for 2013, the President proposed to reduce the number of teaching positions in Ukraine by $33 \%$. Thus, this reduction affects $30-48$ thousand Ukrainian scientists and educators. According to the study of L. Hrynevych, the main purpose of this plan is to achieve formal indicators, not the quality of education (Hrynevych, 2013).

Parliamentarians will try to help university teachers who are taking an appeal to the President to stop the savings on education and the sciences. Otherwise, the layoffs will provoke a new wave of intellectual migration from Ukraine.

In our previous studies (Koshulko, 2013), we proposed reducing the number of branches and departments of the Ukrainian higher education institutions, to focus on the principles of quality education rather than quantity, because the number of universities in Ukraine together with their branches and departments are considerably higher than in the major European countries. Of course, first of all, it is the reduction of branches and departments scattered in different cities, because these branches devalue higher education in general, and are a favorable environment for corruption.

Even without the President's scheduled dismissal to reduce the number of teaching positions in Ukraine, the number of scientists and educators has steadily declined during the last twenty years. According to the State Statistics Service of Ukraine, the total number of scientists and educators from 1991 to 2012 was decreased by 74\% (Anon, 2013A).

In this case, the main goal of the Ministry of Education and Science of Ukraine should be to preserve the quality of the human capital of the Ukrainian scientists and educators.

\section{THE CRITERIA FOR ASSESSING THE HUMAN CAPITAL OF THE UKRAINIAN SCIENTISTS AND EDUCATORS}

How can the human capital of the Ukrainian scientists and educators be evaluated? What are the criteria for the assessment?

We propose the following criteria for assessing the human capital of the Ukrainian scientists and educators:

a) Through the level of English, because English is the language of international communication;

b) Through the degree of integration of each individual scientist and educator in the world and the European scientific community (international grants, scholarships);

c) Through the number of joint projects with foreign scholars;

d) Through the publishing of Englishlanguage articles in the international scientific journals that have strong influence (Koshulko, 2013).

The state should be encouraging Ukrainian scientists and educators to be competitive, to 
develop their human capital, to support their publication as of the results of their research in the international journals, etc. (Koshulko, 2012B).

Otherwise, the dismissal of scientists and educators without the qualitative assessments of their human capital can be regarded as illconceived and the causing of irreparable harm for Ukraine that will stimulate a new wave of intellectual migration, which is fraught with irreversible consequences for the sciences, education, and, ultimately, for the Ukrainian society as a whole (Makazan, 2013).

\section{THE CONSEQUENCES OF ILL- CONCEIVED AND INEFFECTIVE REFORMS IN EDUCATION AND SCIENCE FOR UKRAINE}

As noted, Ukraine cannot demonstrate any benefits that have come its way in connection with post-Soviet changes to its higher education system since 1991. If, to this situation we add the dismissal of 30-48 thousand scientists and educators with their qualitative human capital, this means that the dispersion of the accumulated high-quality human capital from Ukraine continues, and the country will be much more isolated from worldwide innovation and progress. Also, the country can forever lose its status as a scientific state over the next $5-10$ years, as a consequence of having the very lowest level of public spending on science in Ukraine today.

According the studies of L. Hrynevych, now it is not possible to talk about the development of science with the very low current level of public spending on science in Ukraine, because the current level of $0.29 \%$ of GDP of public spending on science in the state is at its lowest since the independence of the country.

At the same time public spending on science, guaranteed by Ukrainian law, is $1.7 \%$ of GDP in Ukraine, while the average level of public spending on science worldwide is $2 \%$. As a result, according to the studies of L. Hrynevych and Osvita.ua, through the current level of very low public spending on science in Ukraine, the country can forever lose its status as a scientific state over the next 5-10 years (Anon, 2013B).

Therefore, the intellectual migration from the country is the consequence of the absence of reforms in the state. The country needs urgent reforms, because otherwise the lag in education, science, and also in socio-economic and cultural areas in comparison to other countries will be more noticeable every year. Scheme 1 will introduce the causes and consequences of intellectual migration, brain drain, from Ukraine.

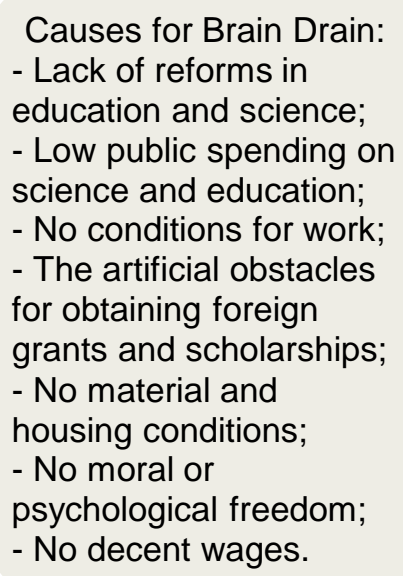

Consequences of Brain Drain: - Lack of reforms in the state; - The significant lag in education, science, and in socio-economic and cultural areas;

- Isolation from worldwide innovation and progress; - Political and socio-economic crisis;

- Loss the status of the scientific country.

\section{Scheme 1 The causes and consequences of intellectual migration, Brain Drain, from Ukraine}

\section{CONCLUSIONS}

The dilemma is that the country's best scientists and educators leave. Ukraine has created all of the conditions for brain drain. This phenomenon is still in progress in the country, because the modern Ukrainian system of education and science does not allow the Ukrainian progressive 
scientists to evolve and get a worthwhile reward as the fruits of their labor in their country of origin.

They are mobile and active, they speak foreign languages, they have international contacts with foreign universities abroad, and their talents and achievements have already been appreciated abroad. After all, only reforms in the system of education and science in Ukraine can make a difference with the brain drain of the country.

Today, the country needs real reforms that can accumulate the human capital of Ukrainian scientists and educators through the creation of decent living and working conditions for them inside the country, not abroad.

Therefore, the main goal of the Ministry of Education and Science of Ukraine should be to preserve the true quality of the human capital of the Ukrainian scientists and educators for the future of Ukraine.

But if the country will not change its strategy for the better in the development of the system of education and science in Ukraine in the near future, the state will continue irreparably to lose the human capital of its best scientists and educators, who could otherwise help to raise the country to the level of one of the advanced countries of the world.

So, the intellectual migration from the country is the consequence of absence of reforms in the state. The country needs the urgent reforms, because otherwise lag in education, science, and also in socio-economic and cultural areas in comparison to other countries will be noticeable more and more every year.

\section{WORKS CITED}

Abreu Bastos, O., \& Koshulko, V. (2013). The decline of human capital in Ukrainian education and science: the experience of reversal, MEST-Journal, Vol. 1, No. 2, 106-113.

Anon. (2012). Donetsk University can lose its heating, and the problem is similar in the whole country. Retrieved from ZIK: http://zik.ua/ua/news/2012/11/30/381509

Anon. (2013A). State Statistics Service of Ukraine. Retrieved from the official website of the State Statistics Service of Ukraine: http://www.ukrstat.gov.ual

Anon. (2013B). Ukraine may lose its status as a scientific state. Retrieved from Osvita.ua: http://osvita.ua/vnz/news/34953/

Borodina, H. (2003). Human capital in rural areas: the scientific basis, and problems of the state of development. Kiev: IAE UAAN.

Chukhno, A. (2003). The post-industrial economy: theory, practice, and their determination in Ukraine. Kiev: Logos.

Danilishin, B., \& Kutsenko, V. (2006). Intellectual resources in economic growth: how to improve their use. Economy of Ukraine, 1,71 .

Golovinov, O. (2004). Human capital in the system of industrial relations. Donetsk: DonDUET.

Hrynevych, L. (2013). The education development strategy that Parliament should form. Retrieved from Osvita.ua: http://osvita.ua/vnz/news/35781/

Kalts, M. (2012). Transparency International: Ukraine is the most corrupt country in Europe. Retrieved from DW.de: $\quad$ http://www.dw.de/ti-\%D1\%83\%D0\%BA\%D1\%80\%D0\%B0\%D0\%B8\%D0\%BD\%D0\%B0$\% \mathrm{D} 1 \% 81 \% \mathrm{D} 0 \% \mathrm{~B} 0 \% \mathrm{D} 0 \% \mathrm{BC} \% \mathrm{D} 0 \% \mathrm{~B} 0 \% \mathrm{D} 1 \% 8 \mathrm{~F}$

\%D0\%BA\%D0\%BE\%D1\%80\%D1\%80\%D1\%83\%D0\%BC\%D0\%BF\%D0\%B8\%D1\%80\%D0\%BE\%D0\%B 2\%D0\%B0\%D0\%BD\%D0\%BD\%D0\%B0\%D1\%8F-

\%D1\%81\%D1\%82\%D1\%80\%D0\%B0\%D0\%BD\%D0\%B0-\%D0\%B2\%D0\%B5\%D0\%B2\%D1\%80\%D0\%BE\%D0\%BF\%D0\%B5/a-16429006

Karpachova, N. (2003). The state of preserving and protecting the rights of Ukrainian citizens abroad, The Special report of the Commissioner for Human Rights in the Verkhovna Rada N. Karpachova, Holos Ukrayiny, 72, 14-15.

Karpachova, N. (2005). Speech by N. Karpachova, the Ukrainian Parliament Commissioner for Human Rights, during the presentation in Parliament of the Annual Report on the state of human rights and liberties, compliance, and protection in Ukraine, Holos Ukrayiny, 133, 6-8.

Koshulko, O. (2012A). The study of the minimum wage in Ukraine and its impact on the development of human capital, Economic Analysis: Theory and Practice, 7(262), 58-63. 
Koshulko, O., \& Koshulko, V. (2012B). Human Capital in Ukraine: How We Do Not Value What We Have. Lap Lambert Academic Publishing, 180.

Koshulko, O., \& Koshulko, V. (2013). Regression of Human Capital in Ukrainian science and education: International experience in overcoming. National Interests Priorities and Safety, 8(197), 29-35.

Kvit, S. (2013). Modern European, not marginal post-Soviet universities needed. Issue No. 267, 13 April 2013. Retrieved from University World News: http://www.universityworldnews.com/article.php?story=20130411130006882

Makazan, E., Abreu Bastos, O., \& Koshulko, V. (2013). Migration and Gender in Ukraine: Origins, Status, and Consequences, Lap Lambert Academic Publishing. 144.

Meh, O. (2012). National scientific potential: the dynamics of the financial and staffing changes. Retrieved from Research Club: http://www.researchclub.com.ua/jornal/219

Polokhalo, V. (2011). The government oligarchs and the national science impoverishment. Retrieved from Ukrrudprom: http://www.ukrrudprom.ua/digest/Uryad olgarhv ta zubognnya vtchiznyano nauki.html?print

Poplavskaya, J., \& Poplavsky, B. (2002). Economic and philosophical aspects of human capital. Bulletin of the Ukrainian NAS, 12, 14-21.

Skrypnyk, V. (2013). Education abroad: sharing experiences, or brain drain? Retrieved from Osvita.ua: http://osvita.ua/abroad/higher school/articles/34441/

Sych, A. (2013). Higher Education is financially unaffordable for most Ukrainians. Retrieved from Osvita.ua: http://osvita.ua/vnz/news/35394/

Received for publication: $\quad 18.10 .2013$

Revision received: $\quad 08.12 .2013$

Accepted for publication: $\quad 21.12 .2013$

\section{How to cite this article?}

Style - APA Sixth Edition:

Abreu Bastos, O., \& Koshulko, V. (2014, 01 15). Intellectual migration as an issue of contemporary education in Ukraine. (Z. Čekerevac, Ed.) MEST Journal, 2(1), 30-36. doi:10.12709/mest.02.02.01.04

Stile - Chicago Fifteenth Edition

Abreu Bastos, Oksana, and Vladyslav Koshulko. "Intellectual migration as an issue of contemporary education in Ukraine." Edited by Zoran Čekerevac. MEST Journal (MESTE) 2, no. 1 (01 2014): 30-36.

Style - GOST Name Sort:

Abreu Bastos Oksana and Koshulko Vladyslav Intellectual migration as an issue of contemporary education in Ukraine [Journal] = Intellectual migration in Ukraine // MEST Journal / ed. Čekerevac Zoran. - Belgrade : MESTE, 01 15, 2014. - 1 : Vol. 2. - pp. 30-36. - ISSN 2334-7058 (Online); ISSN 2334-7171.

Style - Harvard Anglia:

Abreu Bastos, O. \& Koshulko, V., 2014. Intellectual migration as an issue of contemporary education in Ukraine. MEST Journal, 15 01, 2(1), pp. 30-36.

Style - ISO 690 Numerical Reference:

Intellectual migration as an issue of contemporary education in Ukraine. Abreu Bastos, Oksana and Koshulko, Vladyslav. [ed.] Zoran Čekerevac. 1, Belgrade : MESTE, 01 15, 2014, MEST Journal, Vol. 2, pp. 30-36. ISSN 2334-7058 (Online); ISSN 2334-7171. 